
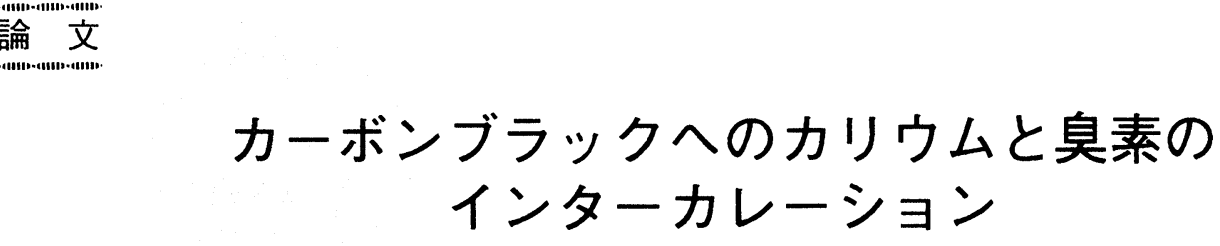

長谷川省治, 原泰夫*, 吉岡久雄**, 阿久沢 昇***

(平成6年4月 25 日受理)

\title{
Intercalation of Potassium and Bromine into Carbon Blacks
}

Shoji Hasegawa, Yasuo Kuwabara, Hisao Yoshioka and Noboru Akuzawa

Chuetsu Kokuen Co., Ltd.,

1-2-27. Hirabayashi, Osaka 559, Japan

* Daiichi Carbon Co., Ltd.,

3888 Ikebecho, Midoriku, Yokohama 226, Japan

** Tokai Carbon Co., Ltd., Aoyama Bldg.

1-2-3 Kita-Aoyama Minato-ku, Tokyo 107, Japan

*** Tokyo National College of Technology,

1220-2 Kunukida Hachioji, Tokyo 193, Japan

Intercalation of potassium and bromine into furnace blacks with different heat-treatmenttemperatures(HTTs) has been investigated. Potassium can be intercalated into carbon blacks irrespective of their HTTs; the saturated compound has the stage 1 structure. The observed isotherms for carbon black-bromine system show that the amount of bromine fixed by carbon black is less than $10 \%$ of that by graphite. The electrical resistance of residue compounds is larger than that of pristine materials for $\mathrm{HTT} \leq 1500^{\circ} \mathrm{C}$ but smaller for $\mathrm{HTT} \geq 2000^{\circ} \mathrm{C}$. Such behavior is discussed in connection with the structure of host carbon blacks.

KEYWORDS: Carbon black, Intercalation, Electrical resistance, Bromine, Potassium

\section{1. 緒言 \\ 炭素材料の特徵はその構造と組織の多様性にあると言 える。同じ物質を原料として炭素化(あるいは黒鉛化)}

(株)中越黒鉛工業所: 7559 大阪市住之江区平林北 1-2-27

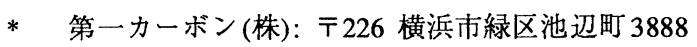

** 東海カーボン(株): 个107 東京都港区北青山1-2-3

*** 東京工業高等専門学校: $\overline{1} 193$ 東京都八王子市椚田 町 1220-2
を行った場合でも，熱処理温度(以下HTTとする)や応力 などの条件を変化させることによって多種多様の炭素材 料が得られる。

黒鉛層間化合物(以下GICとする)のホストとして用い られるのは，HOPGに代表される高配向熱分解黒鉛や天 然黒鉛など結晶性の良好なものが一般的であり，構造解 析や物性測定に有利である。しかし， $\mathrm{KC}_{\boldsymbol{x}}$ による $\mathrm{H}_{2}-\mathrm{D}_{2}$ 分解能は比較的結晶性の低い人造黒鉛(HTT1500)を木ス

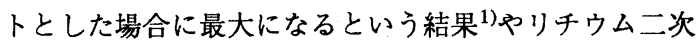
電池の充放電挙動は負極に用いる炭素材料によって異な り，必ずしも結晶性の良好なものが良い特性を示すとい 


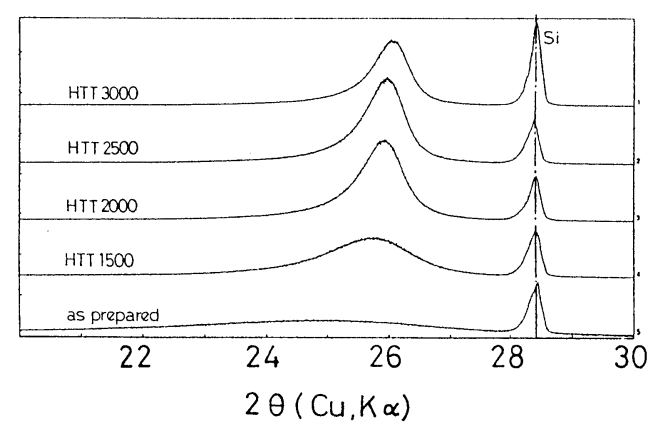

Fig.1 X-ray diffractograms of carbon blacks with different heat-treatment temperatures.

Table 1 X-ray diffraction parmeters, $d(002)$ and $L_{c}(002)$ of carbon blacks.

\begin{tabular}{ccc}
\hline CARBON BLACKS & $d(002) / \mathrm{nm}$ & $L_{c}(002) / \mathrm{nm}$ \\
\hline as prepared & 0.3500 & 2.0 \\
HTT-1500 & 0.3454 & 6.1 \\
HTT-2000 & 0.3431 & 12.7 \\
HTT-2500 & 0.3425 & 14.7 \\
HTT-3000 & 0.3421 & 18.4 \\
\hline
\end{tabular}

うことではないことが報告されている22。このように低 結晶性炭素材料は興味ある化学的特性を持ち, しかも安 価であることより GICの応用を考えるうえで非常に重要 であるが, ホスト効果の定量的議論やデータの蓄積が不 十分である。

本論文はこのような観点から熱处理温度の異なるカー ボンブラックをホストとするインターカレーションにつ いて検討した結果を報告する。

\section{2. 実験}

\section{1 試料}

カーボンブラックはファーネスブラック (東海カーボ ン(株))を用い,いくつかの温度で熱処理を行ったものを 用いた。Fig.1にX線回折測定結果を示した。またこの結 果をもとに算出した構造パラメーター $\left(d_{002}, L_{c}(002)\right)$ を Table 1に示した。な押X線回折測定には $\mathrm{Cu}, \mathrm{K} \alpha$ 線 $(\lambda=$ $0.1548 \mathrm{~nm})$ を用いた。

2.2 キャラクタリゼーション

\subsection{1 酸化挙動}

カーボンブラックの酸化挙動を検討するために TGDTA測定を行った。測定条件は, 試料 $9.5 \mathrm{mg}$, 空気流量 $20 \mathrm{ml} / \mathrm{min}$, 昇温速度 $10^{\circ} \mathrm{C} / \mathrm{min}$ で, 室温から $1000^{\circ} \mathrm{C}$ ま゙温 度を上昇させた。

\section{2 .2 硫酸中のボルタンメトリー}

カーボンブラック $5 \mathrm{mg}$ を白金網(150メッシュ)に包ん だものを作用極とし，対極には同じく白金網，参照極と して水素電極を用いて, $18 \mathrm{M}$ 硫酸中で電位を 0-1.5 V/vs.H.E. $\left(18 \mathrm{M}-\mathrm{H}_{2} \mathrm{SO}_{4}\right)$ の範囲で $1 \mathrm{mV} \cdot \mathrm{s}^{-1}$ の速度でくりか えしスィープしながら電流を記録した。

2.3 カリウムのインターカレーション

カーボンブラック試料に過剩量(モル比で $\mathrm{C} / \mathrm{K}=7$ ) の金 属カリウムを析出させ, $260^{\circ} \mathrm{C} て ゙$ 数日間の熱処理を行っ た。生成物の構造は真空のもとでX線回折測定を行って 決定した。

2.4 臭秦のインターカレーション

2.4.1 アイソサーム

カーボンブラックをスプリングバランスに吊るし， $25^{\circ} \mathrm{C}$ に保持した。臭素圧をコントロールしながら臭素蒸 気をカーボンブラックに接触・反応させ, 重量増加を測 定し，アイソサームを決定した。

\subsubsection{X線回折測定}

カーボンブラックに臭素蒸気を接触させながら X 線回 折測定を行い，臭素化に伴う構造変化を決定した。

\section{4 .3 残存化合物の調製}

カーボンブラックに臭素蒸気を2 3 日間接触・ 反応さ

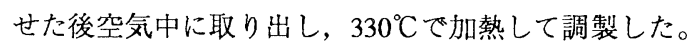

\subsection{4 電気抵抗測定}

残存化合物の電気抵抗測定をJIS-K-1469にしたがって 行った。なお試料の充填高さをいくつか変えて抵抗を測 定し，充填高さを 0 に外捙したときの值を界面抵抗と し, 測定值より差し引いた。

\section{3. 結果および考察}

\subsection{1 空気酸化}

HTT が異なるサンプルを用いて熱分析 (TG-DTA) を 行ったところ, TGで観測される重量減少開始温度およ びDTAで観測される発熱ピーク温度のいずれも HTTの 増加とともに上昇することが確認された。Fig.2に重量減 少開始温度の逆数を $L_{c}$ に対してプロットした結果を示し た。酸化開始温度の逆数は結晶子サイズ $\left(L_{c}\right)$ に大きく依 存することが認められる。さらに $L_{c} \approx 10 \mathrm{~nm}$ を境として $2 つ$ 異なる相関関係が認められる。したがって酸化開 始温度を決定する要因としては, 結晶サイズ $\left(L_{c}\right)$ に加え て何らかの因子が存在するものと考えられる。カーボン ブラックの酸化反応では活性サイト(網面のエッジ)の密 度が重要であると予想される。活性サイトの密度は結晶 子サイズとは負の相関を有すると考えられるので, 結果 的に上述のように酸化開始温度が結晶子サイズ $\left(L_{c}\right)$ の増 加と共に増加しているものと解釈される。その他の酸化 


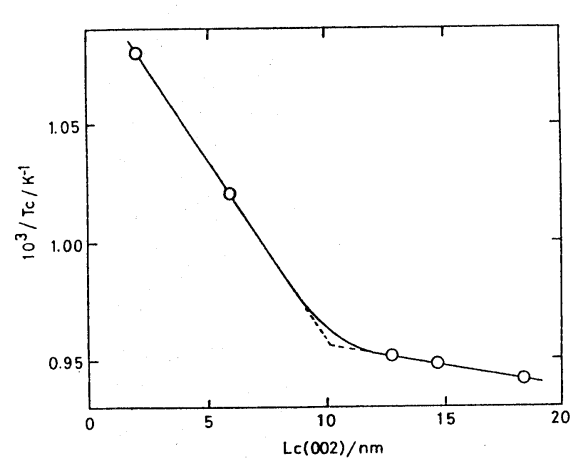

Fig.2 $1 / T_{\mathrm{c}}$ plotted as a function of $L_{c}(002)$, where $T_{\mathrm{c}}$ is the critical temperature for oxidation of carbon black in air.

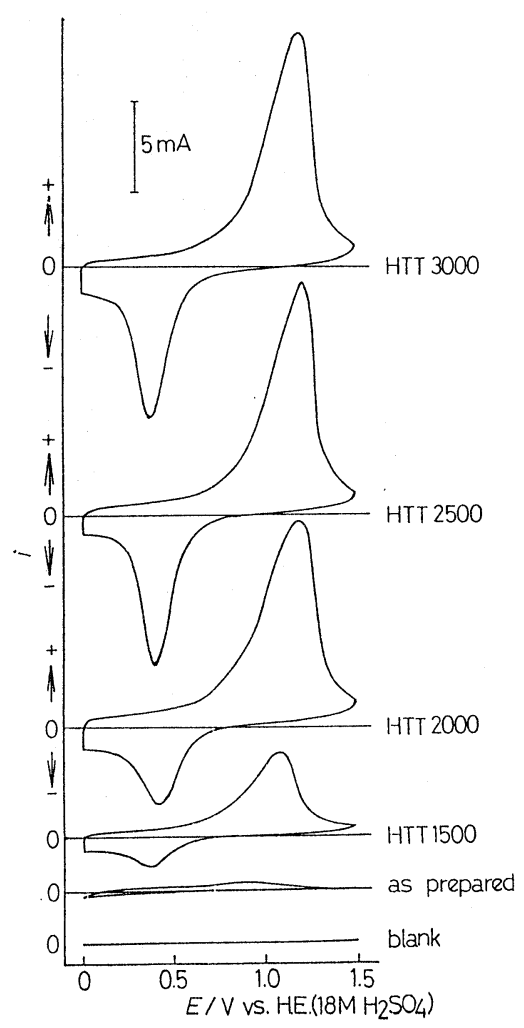

Fig.3 Cyclic voltammograms of carbon blacks in $18 \mathrm{M}$ sulfuric acid.

開始温度に影響を与える因子としは, 表面積, 表面残存 不純物等が考えられるが，今後この点について検討が必 要である。

\section{1 .2 硫酸中のボルタンメトリー}

Fig.3はカーボンブラックの18M硫酸中で観測される ボルタモグラムを HTTの順に下から並べて示したもので
ある。一番下はブランク(白金網)の結果である。ブラン クでは全く電流が流れていないことから，サンプルを白 金網に保持して同様な測定を行ったときに観測される電 流は, カーボンブラック表面で生じている電極反応によ るものであるといえる。as prepared (HTT1000)ではほと んど電流が観測されず, HTTが $1500,2000^{\circ} \mathrm{C}$ と増加する

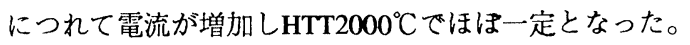
このボルタモグラムのHTTへの依存性は空気酸化挙動の それと対応している。

ここで観測された電流がインターカレーションによる ものであるか酸化反応によるものであるかについては， in-situ X線回折測定結果を待たねばならないが，空気酸 化実験では上述のように低温処理のカーボンブラックの 方が酸化に対して活性であることから，ここで観測され た電流は主としてインターカレーションによるものであ ると思われる。岩下と稲晅は非常に多くの炭素材料を用 いてその構造・組織と硫酸のインターカレーションとの 関係を明らかにしている3)。その結果, $L_{c}(002)$ が $20 \mathrm{~nm}$ より大きければ硫酸のインターカレーションが生じ，そ うでなければ生じないといった規則性を見いだしている (カーボンブラックは取りあげられていない)。本研究で は硫酸と後述の臭素のカーボンブラックヘのインターカ レーションに関して,$d_{002}$ が $0.344 \mathrm{~nm}$ よりさく $L_{c}(002)$ が10nmより大きい場合にはインターカレーションが生 ずることが示唆された。しかしカーボンブラックは, 熱 処理による結晶子サイズと積層秩序や磁気抵抗の変化の 仕方が他の炭素材料と異なることが示唆されている3)の で, 今後,より詳細な調査が必要である。

3.2 カリウムのインターカレーション

Fig.4 にカーボンブラック HTT1500および HTT3000 の試料について, 飽和組成化合物 $\mathrm{KC}_{x}$ と出発カーボンブ ラックのX線回折測定結果を比較して示した。どちらの 場合にもカリウムのインターカレーションによって炭素 の002回折線が消失して，すべての層間にカリウムが挿 入されたステージ 1 構造 (くりかえし周期 $\left(I_{c}\right)=0.54 \mathrm{~nm}$ ) となっている。熱処理を施していないas preparedのサン プルでもカリウムのインターカレーションがX線回折測 定から確認されている。この場合6枚程度の炭素層が積 層しているものと推察されるが, この程度の積層構造で もカリウムがインターカレートすることは興味樑い。こ のようにカリウムの場合は後述の臭素と比較して容易に インターカレーションが進行する。これは石油コークス をホストとした場合でも同様に認められることである が, 低結晶性の炭素材料は電子ドナーとしてよりはむし ろ電子アクセプターとして作用することによるものと推 察される。 $\mathrm{KC}_{x}$ の色はホストの黒色からこげ茶色に変化 
(a) HTT3000

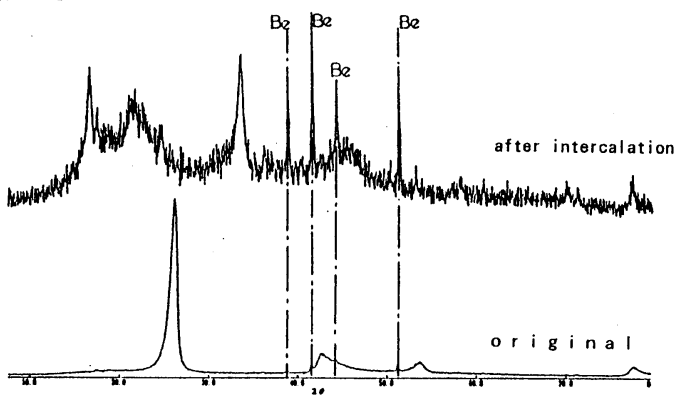

(b)

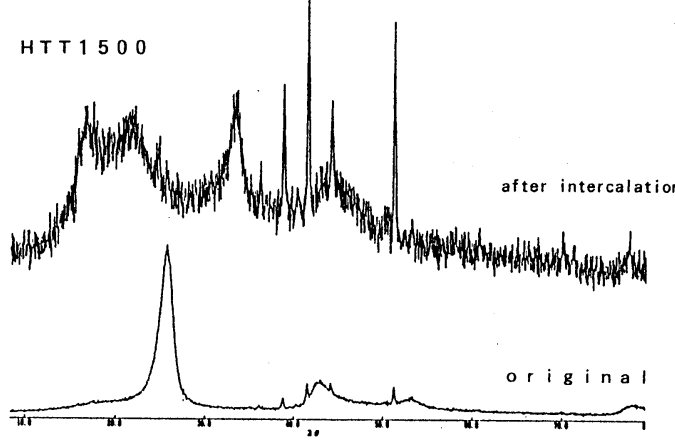

Fig.4 X-ray diffractograms of $\mathrm{KC}_{x}$ and starting carbon blacks for HTT-3000(a) and HTT-1500(b).

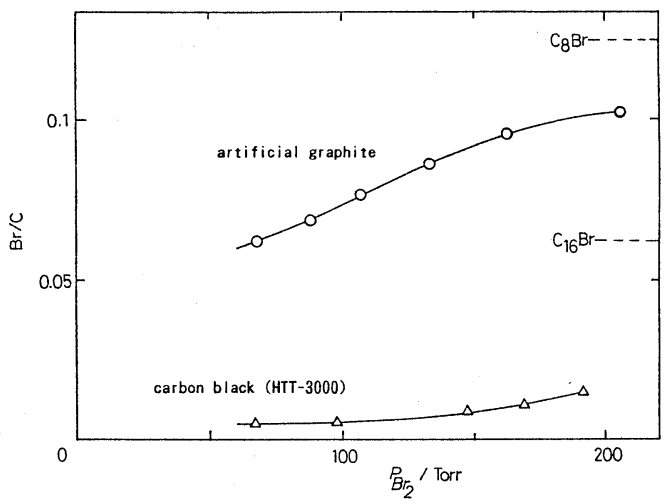

Fig.5 Isotherms of artificial graphite $(\bigcirc)$ and carbon black $(\mathrm{HTT}-3000)(\triangle)$ for the bromination at $25^{\circ} \mathrm{C}$.

しているが, HTTの増加と共に茶色の程度が増大してい る。

3.3 臭菜のインターカレーション

3.3 .1 臭案の吸収アイソサーム

Fig.5はカーボンブラック (HTT3000)のアイソサームを 人造黒鉛(石油コークス, HTT3000)のアイソサームと比 較して示したものである。HTTの異なるカーボンブラッ
クについてもアイソサームを決定したが，HTTによる差 は認められなかった。人造黒鉛の場合には吸収量が大き く, 向坊と高橋の結果4)と一致しているが, カーボンブ ラックでは吸収量はこれより約一桁小さく，臭素圧 180Torr で Br/C=0.0015である。ここで用いたカーボンブ ラックの比表面積は $31 \mathrm{~m}^{2} / \mathrm{g}$ であり，臭素分子サイズ $(0.504 \mathrm{~nm} \times 0.39 \mathrm{~nm})$ を考虑すると単分子層吸着の場合で $\mathrm{Br} / \mathrm{C}=0.0005$ と計算される。このことからカーボンブ ラックでは表面への吸着に相当する程度の量の臭素が固 定されているに過ぎないことがわかる。

\subsubsection{X線回折測定}

臭素化過程のin-situ X 線回折測定を結果をFig.6に示 した。天然黒鉛で，既報4)の結果と同様に臭素のイン ターカレーションに伴って002および004回折線の変化 が，Fig.6(b)に示したように明白に観察されている。と ころが, カーボンブラックの場合にはFig.6(a)に示した ようにホストのピーク位置とBr-GICのピーク位置が重 なってしまい, ピーク位置に変化が認められず，この結 果からインターカレーションが生じているとは言えな い。これと対応して残存化合物のX線回折測定結果にお いても，天然黒鉛の場合には明らかに元のピークとは異 なっているが, カーボンブラックでは明らかな差は認め られない。以上のようにX線回折測定からは，カーボン ブラックへの臭素のインターカレーションが生じている か否かについては明確な解答を得ることができなかっ た。

\subsection{3 臭秦残存化合物の電気抵抗}

カーボンブラックと残存化合物の電気抵抗をFig.7に 比較して示した。HTTが $2000^{\circ} \mathrm{C}$ 以上で抵抗率が臬素化に

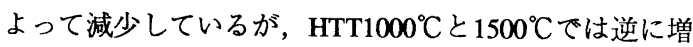
加している。残存化合物の抵抗をカーボンブラックの抵 抗で規格した值 $R / R_{\mathrm{o}}$ を HTT に対してプロットすると Fig.8が得られる。図には $d_{002}$ をHTTに対してプロットし た結果を示されているが，R/R 0 の $\mathrm{HTT}$ 依存と大変よく似 ている。 $d_{002}>0.344 \mathrm{~nm}$ では炭素網面間の相互作用が小さ く，各々の炭素網面の反応性が高いために臭素が炭素網 面を攻撃して共有結合を形成することによって抵抗が増 大しているものと考えられる。一方 $d_{002}<0.344 \mathrm{~nm}$ では電 気抵抗が減少しており，インターカレーションが生じて いることが示唆されている。臭素化したカーボンブラッ ク (HTT3000)の電気抵抗は天然黒鉛や石油コークスなど を用いたときと比較して数倍程度大きい值であった。

\section{4. 結言}

熱処理温度の異なるカーボンブラックをホストとする インターカレーションについて検討した結果, 以下のよ 
(a) carbon black

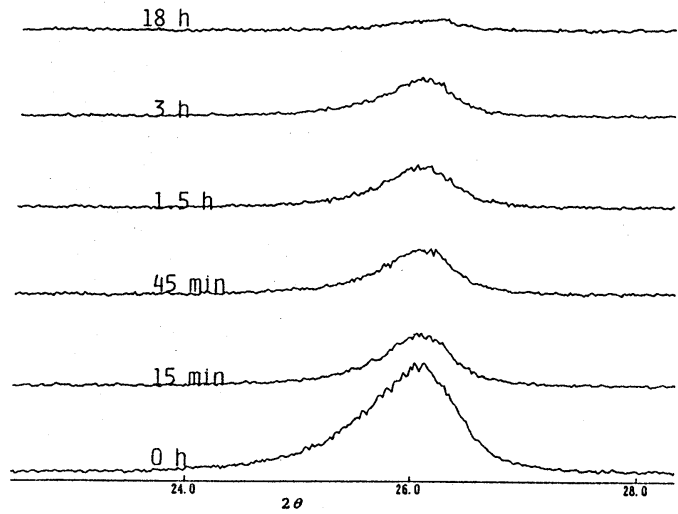

(b) natural graphite

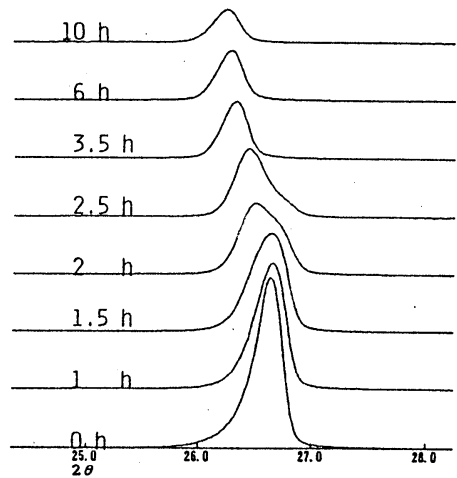

Fig.6 X-ray diffractograms of (a) carbon black and (b) natural graphite during bromination at room temperature.

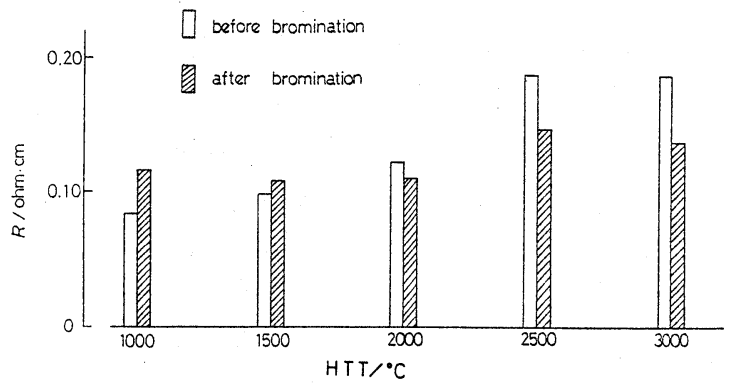

Fig.7 Electrical resistivities of carbon blacks before and after bromination.

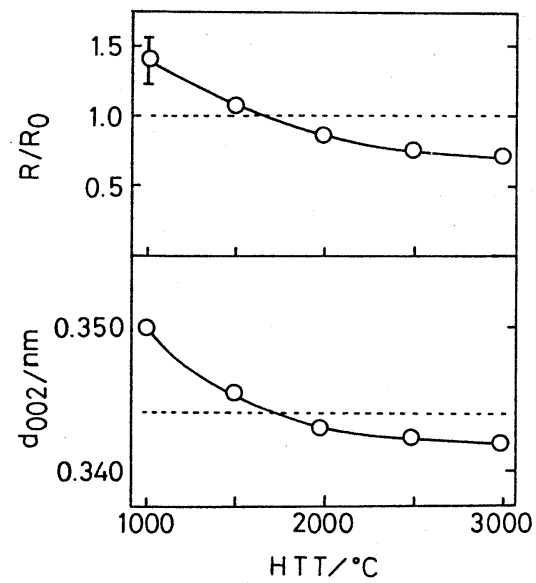

Fig.8 $R / R_{\mathrm{o}}$ and $d_{002}$ plotted as a function of HTT.
うなことが明らかになった。

(1) カーボンブラックをホストとするカリウムと臭素の インターカレーションについてホストの $d_{002} や L_{c}$ との 関連で検討できた。

（2）カリウムは低結晶性のものも含むすべてのカーボン ラックにインターカレートし, 飽和組成ではくりかえ し周期 $\left(I_{c}\right)$ が $0.54 \mathrm{~nm}$ のステージ 1 であった。

(3) カーボンブラックの臭素化にともなう重量増加は人 造黒鉛の場合の約 $1 / 10$ であった。またカーボンブラッ クのHTTの重量増加への影響はほとんどみられなかっ た。

(4) 臭素の残存化合物の電気抵抗は, $\mathrm{HTT} \leq 1500^{\circ} \mathrm{C}$ で 元のカーボンブラックより大きな值となり, 逆にHTT $\geq 2000^{\circ} \mathrm{C}$ ばさい值となった。

\section{謝辞}

本研究を進めるにあたり, 高橋洋一教授 (中央大学), 稲垣道夫教授 (北海道大学), 辰巳国昭氏(大阪工業技術研 究所)より有益なご助言をいただきました。ここに記し て謝意を表します。

\section{文献}

1) T. Terai and Y. Takahashi, Carbon 22 (1984) 91.

2) 辰巳国昭, "Li二次電池と炭素材料", 炭素材料学会 2月セミナーテキスト (1993).

3) N. Iwashita, Dr. Thesis, Hokkaido University (1992).

4) 向坊 隆, 高橋洋一, 工業化学雑誌 45 (1962) 754758. 